\title{
SMALL SCALE FARMERS' PERCEPTION AND ADAPTATION TO CLIMATE CHANGE IN NASARAWA STATE OF NIGERIA
}

\author{
*FALAKI, A.A, AKANGBE, J.A, IYILADE, A.O and OLOWOSEGUN, T. \\ Department of Agricultural Extension, University of llorin, Nigeria \\ *Corresponding author: akindejiayo@yahoo.com
}

\begin{abstract}
Climate change and severe weather events such as temperature shocks and declining rainfall often strongly impede sustainable farming development, especially where agriculture is rain fed and when other external shocks such as poverty, poor access to inputs and credit are common. This is the context in which small scale farmers carry out their farming and other livelihoods activities. This study compares small scale farmers' perception of temperature and rainfall with the result of 30 years (1980-2009) meteorological records of temperature and rainfall, examines the farmers adaptation practices in response to climate change and the constraints to their adaptation. The study found an increasing trend in minimum and maximum temperature and a decline in rainfall trend. This validates the farmers' perception of temperature and rainfall. Tree cutting $(50.7 \%)$ and $\sin (45.7 \%)$ are the perceived leading causes of climate change. Farmers mostly engage in change in planting date (97.8\%), tree planting (77.5\%) and crop diversification (70.3) in response to climate change. Inadequate money (70.3\%) is the leading constraint to adaptation. There is need for extension services and the mass media to create awareness on the causes of climate change. Efforts that address poverty and provide access to agricultural support services like farm inputs and weatherforecasting service will help enhance farmers' adaptive capacity to climate change.
\end{abstract}

Keywords: Adaptation; Climate Change; Perception; Small Scale Farmers.

\section{INTRODUCTION}

Agriculture is one of the sectors highly vulnerable to the impact of climate change, especially in a country like Nigeria where agriculture is rain fed and practiced at the subsistence level. The nature of the impact of climate change on agricultural activities is complex and still being studied. They include but not limited to uncertainty in the onset of farming season due to changes in rainfall pattern, crop failure, pests and diseases migration, decline in agricultural yield and extreme weather events (Mozny et al., 2009; Lobell et al, 2008; Adejuwon, 2006; Washington et al. 2006; Wolfe et al, 2005; Mendelsohn, et al. 2000).

According to Odjugo, (2010), the air temperature pattern in Nigerian since 1901 shows an increasing trend with a sharp rise from the early 1970 s till date. The mean air temperature in Nigeria between 1901 and 2005 was $26.6^{\circ} \mathrm{C}$ while the temperature increase for the 105 years was $1.7^{\circ} \mathrm{C}$. 
This increase in air temperature in Nigeria is higher than the global mean temperature increase of $0.74^{\circ} \mathrm{C}$ recorded since 1860 when actual scientific temperature measurement started (IPCC, 2007). Should this trend continue unabated, Odjugo, (2010) predicted that Nigeria may experience between the middle $\left(2.5^{\circ} \mathrm{C}\right)$ and high $\left(4.5^{\circ} \mathrm{C}\right)$ risk temperature increase by the year 2100 . Odjugo, (2010) also proved that rainfall trend in Nigeria between 1901 and 2005 shows a general decline. Within the 105 years, rainfall amount in Nigeria dropped by $81 \mathrm{~mm}$. The declining rainfall worsened from the early 1970s, and the pattern has continued till date. This period of worsened rainfall decline also corresponds with the period of sharp temperature rise. It was however observed by Odjugo, $(2005,2007)$ that rainfall pattern was disproportionate across the country, as coastal areas experience an increase in rainfall while the continental interiors experience a decrease. These studies (Odjugo, 2005, 2007) also showed that while the areas in the Nigeria experiencing double rainfall maximal is shifting southward, the short dry season ("August Break") is being experienced more in July as against its normal occurrence in the month of August prior to the 1970s. These shifts are major disruptions in climatic patterns of Nigeria showing evidences of a changing climate, leading among other things to farmers' finding it difficult to time their farming operations.

Nigeria is plagued with diverse socio-economic and ecological problems, which are directly linked to climate change (Odjugo, 2005; Ayuba et al. 2007). Mendelsohn and Dinar, (1999) estimated that by 2100 , Nigeria and other West African countries are likely to have agricultural losses of up to $4 \%$ of their Gross Domestic Products (GDP) due to climate change. Agricultural yield in some ecologically sensitive (e.g. the Sahel and Sudan savannah) parts of Nigeria could decline by up to $50 \%$ by 2020 due to the impact of climate change (IPCC, 2007). Shift in crops cultivated, (Odjugo, 2008), reduction of arable lands due to sea incursion and desert encroachment, pests and diseases migration in response to climate change and crop failure are some documented impacts of climate change in Nigeria. Apata, (2006) lamented that as a result of the declining crop yields and unpredictable weather patterns, some farmers are abandoning farming for non-farming activities. According to Ajayi (2009), agriculture in Nigeria employs over $70 \%$ of the population, contributes about $41 \%$ of GDP, accounts for $5 \%$ of total export and provides $88 \%$ of nonoil earnings. Ajayi (2009) further stated that farm holdings in Nigeria fall into three broad categories small scale with 0.1 to 5.99 ha, medium scale with 6-9.99 ha, and large scale with upward of 10 ha, adding that small scale farm holdings predominate in Nigeria, accounting for $81 \%$ of the total area.

IPCC, (2007) indicated that small scale farmers, pastoralists and artisan fisher folk will suffer complex, localised impacts of climate change. These small scale farmers face challenge such as lack of access to production assts and farm inputs, poverty, low literacy level and poor access to agricultural information, which makes them more vulnerable to changes that are beyond their control. To address the issue of climate change, its impact on agriculture and adaptation appropriately, one must therefore take into account small scale farmers' understanding of climate change. Maddison (2006) points out that adaptation to climate change is a two-step process, which initially requires the perception that climate is changing and then responding to changes through adaptation. Within the last decade, there has been a movement among development organizations 
and funding partners such as OXFAM GB to incorporate a more sustainable and participatory approach to agricultural development. The approach involves utilizing the small scale farmer in a more active role, as co-learner and co-participant. This change in roles for the small scale farmer has come about primarily because they have been recognized as a primary player in a successful and sustainable agricultural development strategy. The small scale farmer is being viewed by development agencies not only as a beneficiary, client or co-learner in agricultural extension efforts, but also as contributor of cultural, traditional agricultural and environmental wisdom which could define a more relevant technology and the successful adoption of the technology (Smit and Skinner 2002). Accordingly, there is the need to gain as much information as possible about small scale farmers' perception of climate change, their adaptation strategies and how their adaptive capacity can be improved.

Consequently, the purpose of this study is to investigate small scale farmers' perception and adaptation to climate change in Nasarawa State of Nigeria within the context of development programmes. The specific objectives are to:

i. Examine small scale farmers' perception of temperature and rainfall variation in the study area.

ii. Compare small scale farmers' perception of temperature and rainfall variation with meteorological records in the study area.

iii. Examine adaptation practices adopted by small scale farmers to climate change in the study area.

iv. Examine constraints to climate change adaptation in the study area.

This study will guide policy makers on ways to promote adaptation within sustainable development programmes. It is increasingly argued (for example, Richard and Klein, 2004) that many climate change studies, whilst effective in alerting policymakers to the possible effects of climate change, have had limited usefulness in providing local-scale guidance on adaptation. The study also brings to the fore small scale farmers' knowledge which can be shared and explored in developing adaptation strategies and action plans. It focuses on the local perception of a global problem and how local solutions are being directed to a global challenge.

\section{MATERIALS AND METHODS}

The study area is Nasarawa State of Nigeria. It was created from the old Plateau State on the $1^{\text {st }}$ October, 1996, with Lafia as the State Capital and thirteen (13) local government areas. It has a population of about 2,040,097 according to the 2006 national population census. The State has a land area of approximately $27,116.8$ square kilometres. Nasarawa is located in the Middle-Belt region of Nigeria with coordinates $8^{\circ}, 32^{\prime} \mathrm{N} 8^{\circ}, 18^{\prime} \mathrm{E}$ and $8.5^{\circ} \mathrm{N} 8.3^{\circ} \mathrm{E}$. It lies within the Guinea Savannah region, has tropical climate and is made up of plain lands and hills measuring up to $300 f t s$ above sea level at some points. Rain-fed agriculture at subsistent level is the main stay of the economy. 
The study is based on a survey of one hundred and thirty eight (138) farm household heads during the 2010/2011 farming season in Nasarawa. The farm household heads were beneficiaries of the Strengthening the Livelihoods of Small Scale farmers in Nigeria (SLISSFAN) agricultural programme co-funded by the European Commission and Oxfam GB and executed in partnership with local partners. SLISSFAN local partners assisted in data collection. The study samples were collected from the nine communities (Ikposogye, Musha, Tudu Adabu, Kirayi, Assakio, Rafin kudi, Ahenta, Ogbagi, Gbamze West) spread over three local governments areas (Obi, Lafia, Nasarawa-Eggon) in the State SLISSFAN project.

Primary and secondary data were collected and analysed for the study. From the SLISSFAN project baseline data obtained from Oxfam, household heads who were 40 years old and above and who have lived in the community for 20 years and above were purposively selected and used as the sampling frame. This was done to ensure only farmers that were matured enough to recall temperature and rainfall pattern in their communities were sampled. Simple random sampling (fish bone method) was used to select respondents for the study. Fifteen household heads were selected from each of the 9 participating communities and 3 extra household heads were selected from each of the 3 participating local governments. This was done to ensure balance in the spread of respondents in the study area.

A pre-tested interviewer-administered questionnaire was used to elicit information from household heads selected for the survey. Thirty years (1980 - 2009) meteorological records on temperature and rainfall in the study area were obtained from Nigeria Meteorological Agency (NIMET) for the Jos Station, which accounts for weather records for Nasarawa State.

The time series was used to analyse trends in temperature and rainfall. Regression linear trend lines were plotted using Microsoft Excel 2007 software version, which also produced the estimation of changes in temperature and rainfall. The pattern of temperature and rainfall were depicted using lines and histogram respectively, while trend lines were used to depict the slopes of the rainfall and temperature. Farmers were asked to respond to questions on patterns of temperature and rainfall over the past twenty (20) years, their adaptation practices and constraints to climate change adaptation. Frequency counts and percentages were used to describe the primary data.

\section{RESULTS AND DISCUSSION}

The result of the study shows that $81.9 \%$ of respondents perceived an increase in air temperature while $11.6 \%$ perceived a decrease in air temperature within the last 20 years (Table 1 ). The table further reveal that while $44.9 \%$ of respondents perceived a decrease in rainfall amount, $43.5 \%$ perceived an increase.

The respondents' perception of the causes of the changes in climate over the last 20 years indicate that $50.7 \%$ linked it to tree cutting by humans, $45.7 \%$ claimed it was caused by $\sin , 43.5 \%$ identified bush burning as the cause and $24.6 \%$ claimed it was caused by evil spirits (Table 2). It is 
instructive to note that none of the respondents in the study think climate change is caused by nothing or that it is just a normal, naturally occurring phenomenon. According to IPCC (2007), the changes in the climate system in recent decades is anthropogenically enhanced, i.e., caused by human activities such as bush burning, tree cutting and industrialization among other things. While the perception of the causes of climate change by the farmers is in agreement with IPCC, (2007), a sizeable proportion of the respondents in the study still erroneously ascribe the cause of climate change to sin and evil spirits. The implication of this finding is that small scale farmers need to be enlightened on the meaning, causes and impact of climate change.

Small scale farmers practice a wide array of adaptation options in response to changes in climatic conditions. The leading climate change adaptation practices according to Table 3 are change in planting date (97.8\%), tree planting (77.5\%), crop diversification $(70.3 \%)$ and use of improved crop/livestock species (69.6\%). Change in planting date is cost effective but require good technical knowledge and current information on when it is best to plant. Tree planting could be a response to encroaching desert conditions spreading to the guinea savannah from the Sudan/Sahel savannah and the associated wind storm (Yaqub, 2007; Ogjugo and Ikhuoria, 2003). Trees also serve as shades and eventually as source of fuel wood in rural communities. However, the benefit of tree planting as an adaptation option will take several years to begin to accrue. Furthermore, the use of improved crop/livestock species and crop diversification in response to climate change will require some measure of scientific input, technical knowledge and access to information by the farmers.

In other to respond to the impacts of climate change on different aspects of their farming and livelihoods, farmers engage in a variety of non-farm adaptation options. Table 4 shows that $95.7 \%$ of the respondents resort to prayer/other spiritual exercises. This is followed by $84.8 \%$ who carried out changes in house construction. Other adaptation practices engaged by the respondents were insect (mosquito) management (76.1\%) and engagement in non-farm livelihoods activities $(65.2 \%)$. Changes in house construction by the respondents involved making adjustments in old building and innovative architecture in new ones that provide ventilation and use less heat conducting materials. Insect (mosquito) management in the study area include the burning of dry leaves that produce a unique smell that dispel mosquitoes. Non-farm adaptation activities in response to climate change in the study area includes petty trading, daily movement to nearby towns to work as car wash men, drivers and bus conductors.

An understanding of what is preventing small scale farmers from adapting their farm operations and livelihoods activities to changes in the climate will assist policy makers and development partners in planning appropriate and effective intervention programmes to build the farmers' resilience to climate change and also reduce their vulnerability to the impacts of the climatic changes. According to Table 5, inadequate financial resource was indicated by $70.3 \%$ of the respondents as a constraint in adjusting farm operations to the changing climate. Other common constraints were inadequate knowledge of appropriate adaptation options (39.9\%), inadequate information on weather $(38.4 \%)$, inadequate access to required farm inputs $(37.7 \%)$ and shortage of farm land (34.8\%). The implication of this finding is that for climate change 
adaptation strategies for small scale farmers to be effective, it should not impose heavy financial burden on the farmers. Weather forecasting services, awareness and capacity building on climate change adaptation options as well as provision of necessary farm inputs should also be incorporated into adaptation options for small scale farmers.

Figure 1 shows an increasing trend in minimum temperature for Jos meteorological station. During the 30 years period, the minimum temperature has risen by $0.58^{\circ} \mathrm{C}\left(\mathrm{y}^{0}=15.4+\right.$ $0.02 \mathrm{x}$ ) fluctuating between the lowest of $13.9^{\circ} \mathrm{C}$ in 1989 and the highest of $17.1^{\circ} \mathrm{C}$ in 2008 , with mean of $15.7^{\circ} \mathrm{C}$ and standard deviation of 0.35 . Four of the five highest minimum temperature years recorded within the period has been within the last 5 years. Figure 2 shows an increasing trend in maximum temperature trend for Jos meteorological station. During the 30 years period, the maximum temperature has risen by $0.55^{\circ} \mathrm{C}\left(\mathrm{y}^{0}=27.5+0.02 \mathrm{x}\right)$, with the lowest in $1992\left(26.9^{\circ} \mathrm{C}\right)$ and highest in $2008\left(28.9^{\circ} \mathrm{C}\right)$, with mean of $27.8^{\circ} \mathrm{C}$ and standard deviation of 0.44 . Given that $81.9 \%$ of the respondents perceived an increase in air temperature, it can be inferred that the farmers' perception of temperature in the study area appear to be in accordance with meteorological records in the region.

Figure 3 shows the total annual rainfall amount trend for Jos meteorological station for the period 1980 to 2009 and presents a decreasing trend. Over the 30 years period, total annual rainfall amount has decreased by $-8.48 \mathrm{~mm}\left(\mathrm{y}^{0}=107.10 .29 \mathrm{x}\right)$. The mean total yearly rainfall amount is $102.9 \mathrm{~mm}$, with lowest rainfall of $814 \mathrm{~mm}(1995)$ and highest of $1582 \mathrm{~mm}(2002)$. Given that the highest proportion of the respondents $(44.9 \%)$ perceived that rainfall amount is decreasing, the farmers' perception is in harmony with meteorological records in the area. Figure 4 presents the wet season average rainfall amount in 5 years period for Jos from 1980 2009. It revealed that July and August consistently had the highest rainfall amount. Also, there is an increase on rainfall trend in August ( $18.24 \mathrm{~mm} / 30$ years), but a decrease in rainfall trend in May $(22.23 \mathrm{~mm} / 30$ years) and July (45.75mm/year). Again, this is contrary to previous climatic records in Nigeria which shows double rainfall maxima in June and September with a break in August (FME, 2003). This underscores the unpredictability of rainfall. It also supports the findings of Odjugo (2005) and Odjugo (2007) that the short dry period during the raining season commonly known as the August break is shifting to July.

\section{CONCLUSIONS}

This study demonstrates that the climate is changing and farmers are able to correctly perceive the changes in the climate trend. Furthermore, the study reveals that farmers engage in a variety of farm and non-farm practices to adapt to the changing climate, but they face constraints such as inadequate financial resources and poor access to inputs and the required information on weather and agriculture, in adapting their farming operations and livelihoods to climate change. These constraints will limit the farmers' ability to respond to current climate change regime and extreme weather incidences. It is recommended that policy makers and development partners collaborate with small scale farmers in terms of information exchange in developing appropriate 
policies and programmes that will build the farmers' adaptive capacity. Development efforts in rural agrarian communities should also incorporate climate change information initiatives, weather forecasting services and access to agricultural inputs.

\section{ACKNOWLEDGEMENT}

Data collection for this research was done in partnership with Oxfam GB SLISSFAN Project Partners in Nasarawa State; ProjectAgape and Young Men Christian Association (YMCA).

\section{REFERENCES}

Adejuwon, J.O. (2006). Food Security, Climate Variability and Climate Change in Sub-saharan West Africa. Assessments of Impacts and Adaptations to Climate Change (AIACC), Project No. AF 23, AFinal Report, AIACC Project Office, Washington, DC.

Ajayi, S. (2009). Impact of Climate Change on Food Security in Nigeria. Agricultural Show Seminar, Tudun Wada, Karu LGA, Nasarawa State.

Apata, T.G. (2006) .Income and Livelihood Diversification Strategies in Oil Producing Areas of Ondo State, Nigeria. Ph.D. Thesis in the Department of Agricultural Economics, University of Ibadan, Ibadan, Nigeria pp: 201+ix

Ayuba, H.K., Maryah, U.M. \& Gwary, D.M. (2007). Climate Change Impacts on Plant Species Composition in Six Semi-arid Rangelands of Northern Nigeria. Nigerian Geographical Journal. 5(1):35-42.

FME (2003). Nigeria's First National Communication under the United Nations Framework Convention on Climate Change. Federal Ministry of Environment, Abuja, Nigeria.

IPCC (2007). Climate Change 2007: Impacts, Adaptation and Vulnerability: Contribution of Working Group II to the Fourth Assessment Report of the Intergovernmental Panel on Climate Change. Cambridge University Press, Cambridge

Lobell, D.B., Burke, M.B., Tebaldi, C., Mastrandrea, M.D., Falcon, W.P. \& Naylor, R.L. (2008). Prioritizing Climate Change Adaptation Needs for Food Security in 2030. Science, 319(5863):607610

Maddison, D. (2006). The Perception of and Adaptation to Climate Change in Africa. CEEPA Discussion Paper No. 10. Centre for Environmental Economics and Policy in Africa. Pretoria, South Africa: University of Pretoria. 
Mendelsohn, R., Morrison, W., Schlesinger, M., \& Andronova, N. (2000). Country Specific Impacts of Climate Change. The World Bank Group.

Mendelsohn, R. and Dinar, A. (1999). Climate Change, Agriculture and Developing Countries: Does Adaptation Matter? The World Bank Research Observer, 14:277-293.

Mozny, M., Tolasz, R., Nekovar, J., Sparks, T., Trnka, M. \& Zalud, Z. (2009). The Impact of Climate Change on the Yield and Quality of Saaz hops in the Czech Republic. Agricultural and Forest Meteorology, 149:913-919

Odjugo, P.A.O. (2010). General Overview of Climate Change Impacts in Nigeria. Journal of Human Ecology, 29(1):47-55.

Odjugo, P.A.O. (2008). Quantifying the Cost of Climate Change Impact in Nigeria: Emphasis on Wind and Rainstorm. Journal of Human Ecology, 28(2):93- 101.

Odjugo, P.A.O. (2007). The Impact of Climate Change on Water Resources: Global and Regional Analysis. The Indonesian Journal of Geography, 39:23-41.

Odjugo, P.A.O. (2005). An Analysis of Rainfall Pattern in Nigeria. Global Journal of Environmental Science, 4(2):139-145.

Odjugo, P.A.O. and Ikhuoria, A.I. (2003). The Impact of Climate Change and Anthropogenic Factors on Desertification in the Semi-arid Region of Nigeria. Global Journal of Environmental Science, 2(2):118-126.

Richard, J.T. and Klein, O. (2004). Approaches, Methods and Tools for Climate Change Impact, Vulnerability and Adaptation Assessment. Keynote Lecture to the In-Session Workshop on Impacts of, and Vulnerability and Adaptation to, Climate Change, Twenty-First Session of the UNFCCC Subsidiary Body for Scientific and Technical Advice, Buenos Aires, Argentina, 8 December 2004.

Smit, B. and Skinner, M. (2002). Adaptation Options in Agriculture to Climate Change: A Typology. Mitigation and Adaptation Strategies for Global Change, 7: 85-114.

Washington, R., Harrison, M., Conway, D., Black, E., Challinor, A., Grimes, D., Jones, R., Morse, A., Kay, G. \& Todd, M. ( 2006). African Climate Change: Taking the Shorter Route. Bulletin of the American Meteorological Society, 87:13551366. 
Wolfe, D.W., Schwartz, M.D., Lakso, A.N., Otsuki, Y., Pool, R.M. \& Shaulis, N.J. (2005). Climate Change and Shifts in Spring Phenology of Three Horticultural Woody Perennials in NorthEastern USA. Journal of Biometeorology, 49:303-309.

Yaqub, C.N. (2007). Desert Encroachment in Africa: Extent, Causes and Impacts. Journal of Arid Environment, 4(1):14-20.

Table 1 Distribution of Respondents by Perception of Temperature and Rainfall within the Last 20 years

\begin{tabular}{l|ll}
\hline & Frequency & Percentage (\%) \\
\hline Air Temperature & & \\
Increased & 113 & 81.9 \\
Decreased & 16 & 11.6 \\
Stayed Same & 3 & 2.2 \\
Dont know & 6 & 4.3 \\
Total & 138 & 100.0 \\
& & \\
Rainfall Amount & & \\
Increased & 60 & 43.5 \\
Decreased & 62 & 44.9 \\
Stayed Same & 9 & 6.5 \\
Dont know & 7 & 5.1 \\
Total & 138 & 100.0 \\
\hline
\end{tabular}

Source: Field Survey, 2011 
Falaki, Akangbe, Iyilade and Olowosegun

Table 2 Distribution of Respondents by Perception of Causes of Climate Change

\begin{tabular}{l|ll}
\hline & Frequency & Perception (\%) \\
\hline Industrialization & & \\
Bush Burning & 17 & 12.3 \\
Tree Cutting & 60 & 43.5 \\
Sin & 70 & 50.7 \\
Evil Spirits & 63 & 45.7 \\
Nothing & 34 & 24.6 \\
\hline
\end{tabular}

Source: Field Survey, 201

*Multiple Responses

Table 3 Distribution of Respondents by On-farm Adaptation Options to Climate Change

\begin{tabular}{l|cc}
\hline Farm Adaptation Options & Frequency & Percentage (\%) \\
\hline & 135 & 97.8 \\
Change Planting Date & 96 & 69.6 \\
Improved Crop/Livestock & 97 & 70.3 \\
Crop Diversification & 107 & 77.5 \\
Tree Planting & 69 & 50.0 \\
Soil/Water Conservation & 75 & 54.3 \\
Irrigation & & \\
Change in Farming Type (crop & 80 & 58.0 \\
to livestock vice versa) & & \\
Livestock Management & 79 & 57.2 \\
\end{tabular}

Source: Field Survey, 2011

*Multiple Responses 
Falaki, Akangbe, Iyilade and Olowosegun

Table 4 Distribution of Respondents by Non-farm Adaptation Options to Climate Change

\begin{tabular}{l|cc}
\hline & & \\
Non-farm Adaptation Options & Frequency & Percentage (\%) \\
\hline & & \\
Changes in House Construction & 117 & 84.8 \\
Insect (Mosquito) Management & 105 & 76.1 \\
Involvement in Non-farm Activities & 90 & 65.2 \\
Prayers/Spiritual Exercise & 132 & 95.7 \\
\hline
\end{tabular}

Source: Field Survey, 2011

*Multiple Responses

Table 5 Distribution of Respondents by Constraints in Adjusting Farm Practices to Changes in Climatic Conditions

\begin{tabular}{l|ll}
\hline \multicolumn{1}{c|}{ Constraint $^{\star}$} & Frequency & Percentage (\%) \\
\hline Inadequate information on weather & 53 & 38.4 \\
Inadequate Knowledge of Adaptation Options & 55 & 39.9 \\
Inadequate Financial Resource & 97 & 70.3 \\
Shortage of Farm Land & 48 & 34.8 \\
Inadequate access to Farm Inputs & 52 & 37.7 \\
Inadequate Irrigation Water & 30 & 21.7 \\
Shortage of labour & 37 & 28.8 \\
\hline
\end{tabular}

Source: Field Survey, 2011. *Multiple Responses

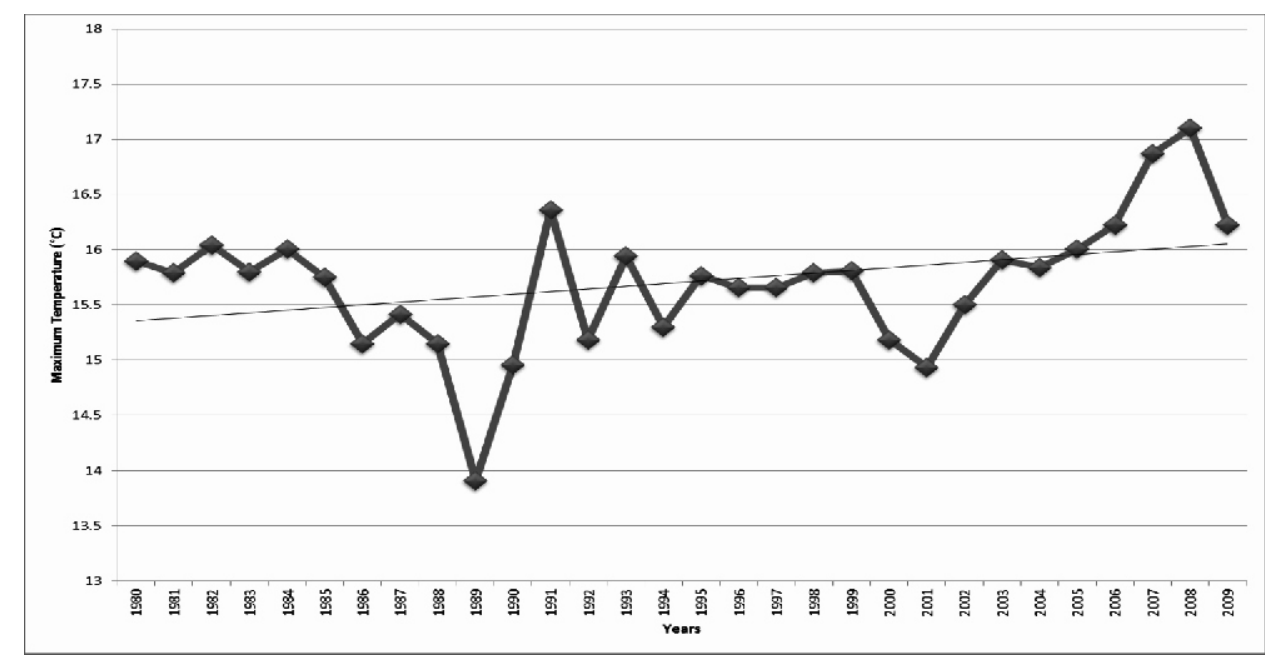

Figure 1 Trend of Minimum Temperature for Jos from 19802009 


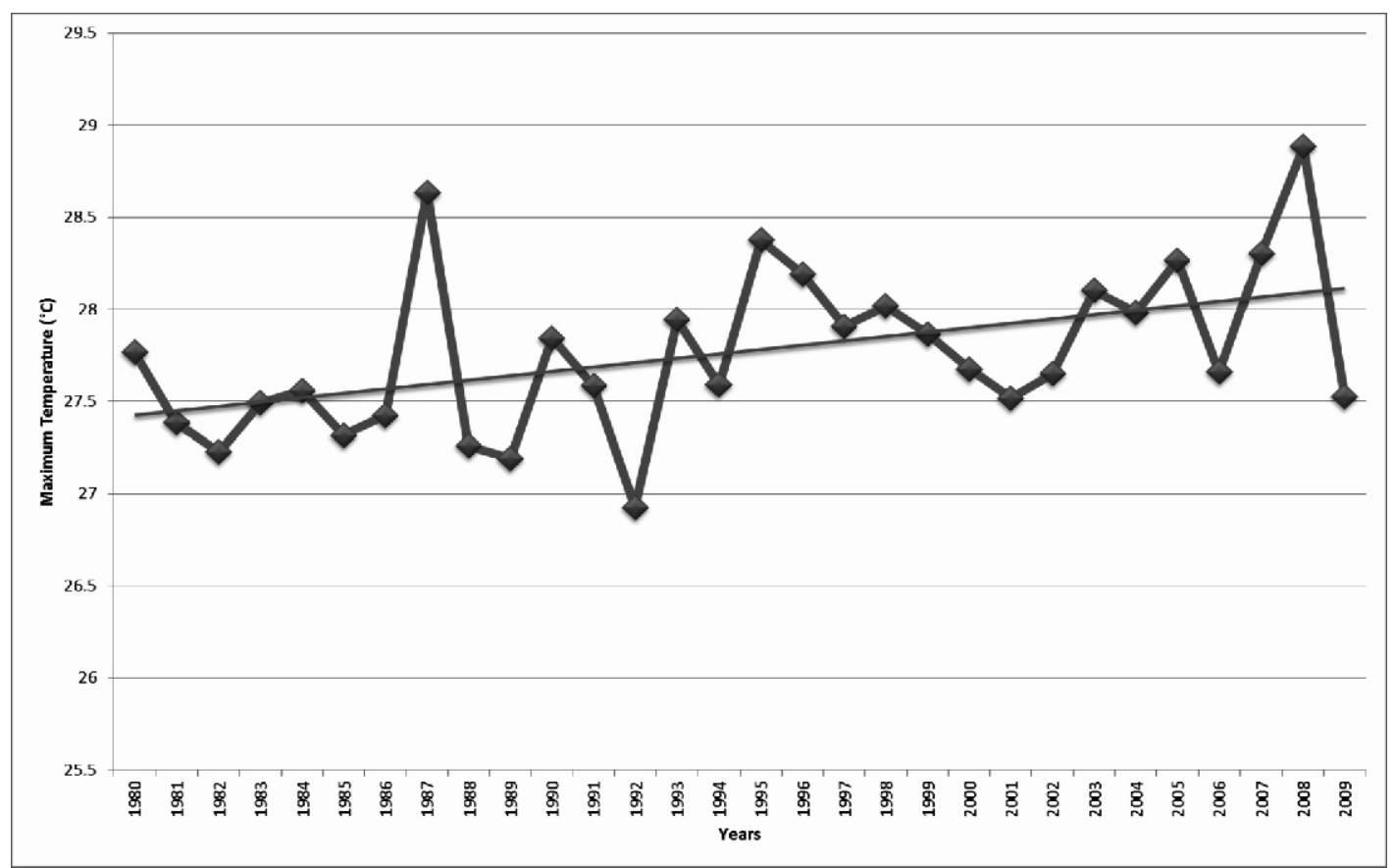

Figure 2 Trend of Maximum Temperature for Jos from 19802009

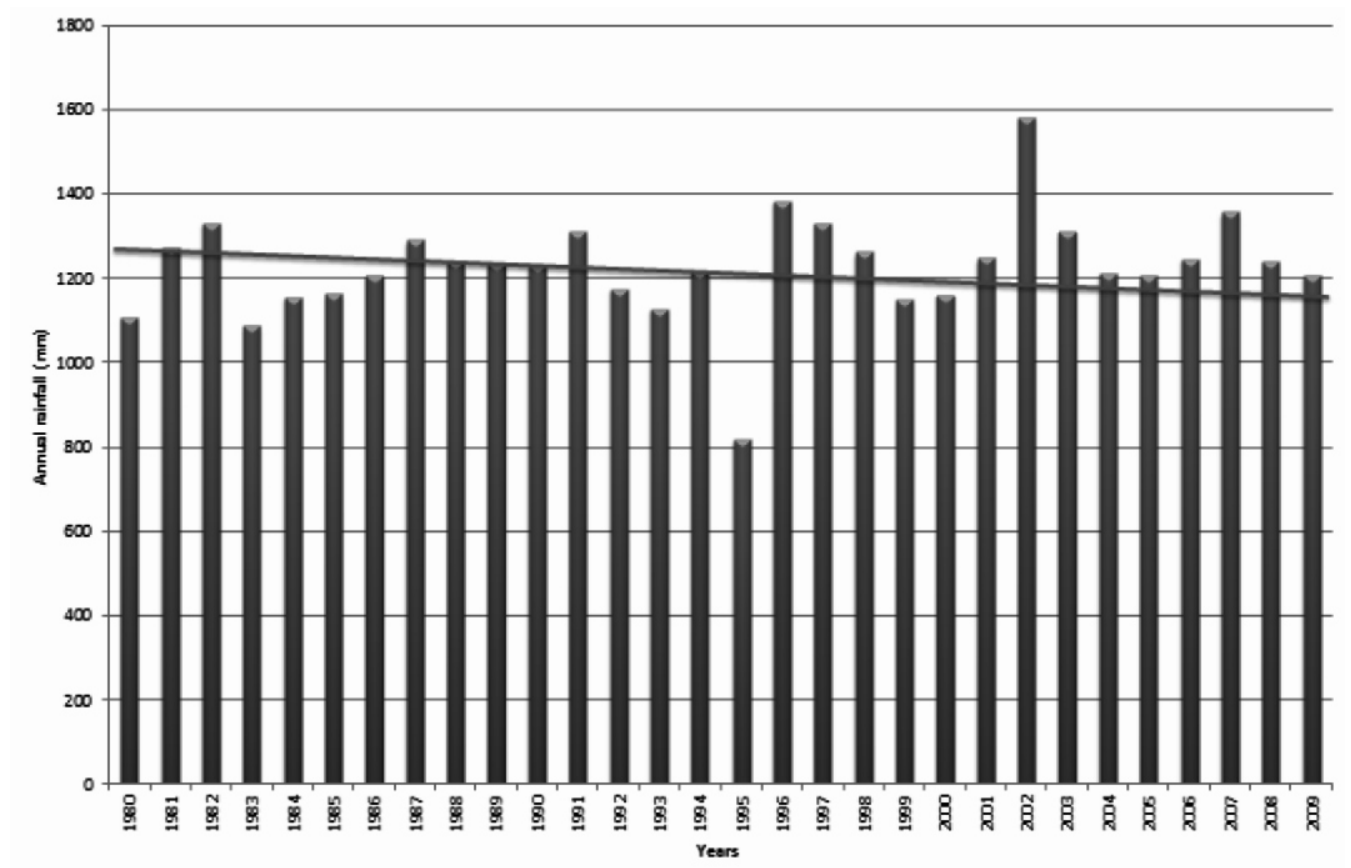

Figure 3 Trend of Rainfall Amount for Jos from 19802009 
Falaki, Akangbe, Iyilade and Olowosegun

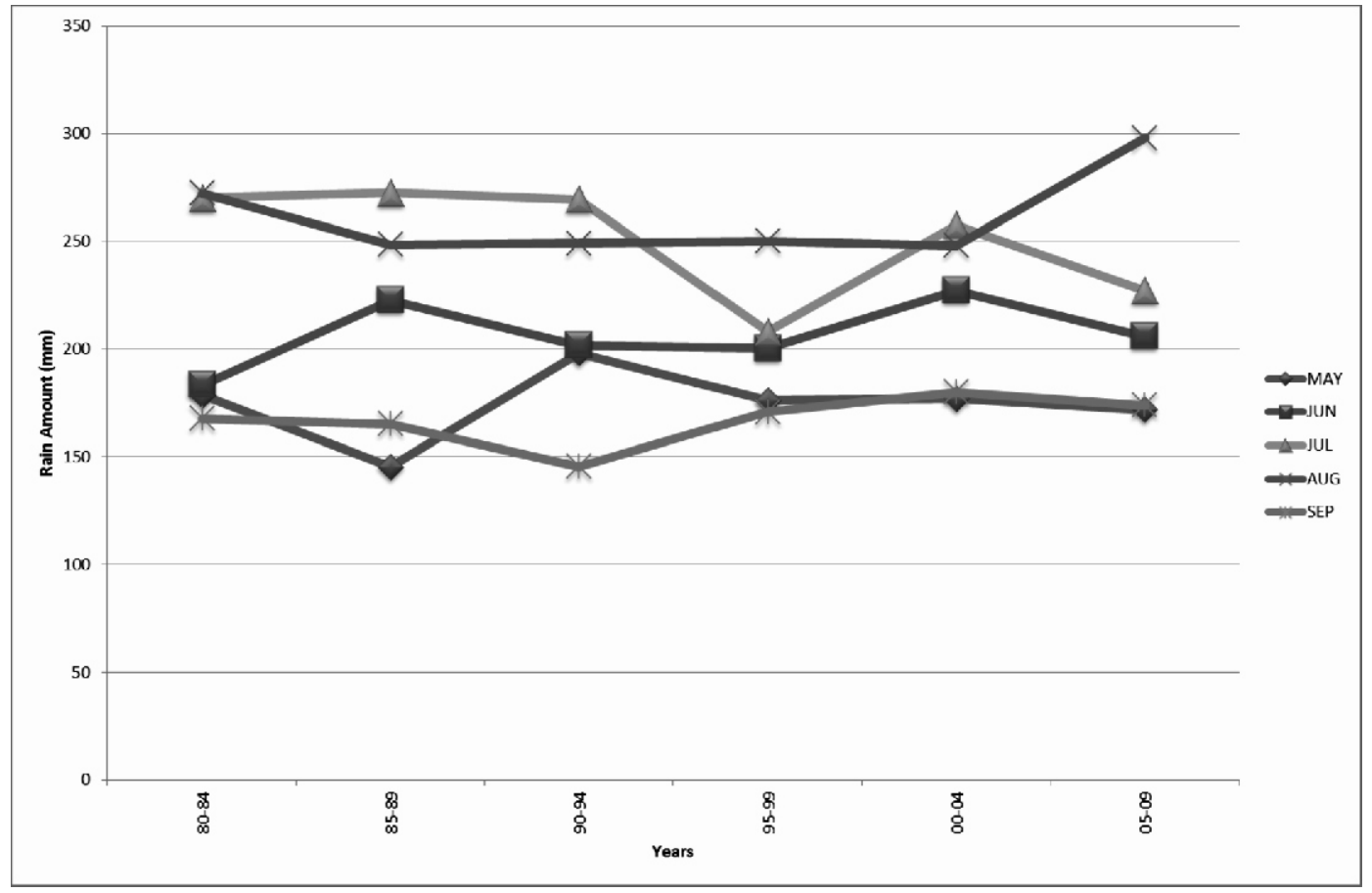

Figure 4 Wet Season Average Rainfall (Five Yearly) for Jos from 19802009 